\title{
A conservation checklist of the amphibians and reptiles of Mexico City, with comparisons with adjoining states
}

\author{
Julio A. Lemos-Espinal', Geoffrey R. Smith² \\ I Laboratorio de Ecologia-UBIPRO, FES Iztacala UNAM, Avenida los Barrios 1, Los Reyes Iztacala, Tlal- \\ nepantla, edo. de México, 54090, México 2 Department of Biology, Denison University, Granville, Ohio \\ 43023, USA
}

Corresponding author: Julio A. Lemos-Espinal (lemos@unam.mx)

Academic editor: Annemarie Ohler | Received 26 March 2020 | Accepted 5 June 2020 | Published 22 July 2020

http://zoobank.org/F9DE6895-7032-41AA-A38B-4B1281EB7E4C

Citation: Lemos-Espinal JA, Smith GR (2020) A conservation checklist of the amphibians and reptiles of Mexico City, with comparisons with adjoining states. ZooKeys 951: 109-131. https://doi.org/10.3897/zookeys.951.52578

\begin{abstract}
Mexico City houses one of the most populous urban areas of the world, and the modification of its natural habitat likely influences the biological diversity found there. In particular, amphibians and reptiles are likely affected by these modifications. Herein, we present an updated list of the species of amphibians and reptiles that inhabit Mexico City. Mexico City harbors 65 species of amphibians and reptiles, which represent 21 families and 33 genera. These include 18 species of amphibians (nine anurans and nine salamanders) and 47 species of reptiles (14 lizards, 30 snakes [one introduced], and three turtles [one introduced]). Forty-eight of the amphibian and reptile species in Mexico City are endemic to Mexico, with two endemic to Mexico City. The most diverse region of Mexico City is the Forests and Ravines region, which is home to 43 species. Eleven species of amphibians and reptiles in Mexico City are IUCN listed, 16 are placed in a protected category by SEMARNAT (Secretaria del Medio Ambiente y Recursos Naturales), and 27 species are categorized as high risk by the EVS (Environmental Viability Score). Mexico City shares almost 94\% of its species with the State of Mexico.
\end{abstract}

\section{Keywords}

amphibians, frogs, herpetofauna, lizards, reptiles, salamanders, snakes, turtles 


\section{Introduction}

Since pre-Hispanic times the Basin of Mexico, upon which Mexico City (formerly Mexico, Distrito Federal) sits, caught the attention of the inhabitants of central Mexico. This large lake surrounded by fertile land was the location of important human settlements that, at the arrival of the Spaniards, were represented mainly by Tenochtitlan, which along with a large number of villages located around the basin reached over a million inhabitants (Wikipedia: https://es.wikipedia.org/wiki/Ciudad_ de_M\%C3\%A9xico - accessed 27 December 2019). At the arrival of the Spaniards, in 1519 , the basin was occupied by a well-developed civilization whose economy revolved around the Chinampas that surrounded the lake (Fig. 1). With the Spanish conquest of Mexico, cattle were introduced to the basin and a radical transformation began, including the drying of the Basin and the felling of the forests that surrounded it. The population around the Basin began to decline to such extent that at the end of the $18^{\text {th }}$ century the number of inhabitants in Mexico City was only 120,000. It was not until the middle of the $20^{\text {th }}$ century that the population explosion began creating diverse and complex problems that today overwhelm Mexico City (Imaz 1989). Currently the population of Mexico City is approximately 8.9 million inhabitants; however, including the metropolitan area of the Valley of Mexico, which extends over the Basin of Mexico, the population totals 22 million inhabitants, the ninth most populated urban area in the world, and the largest in the Americas (Wikipedia: https://es.wikipedia.org/ wiki/Ciudad_de_M\%C3\%A9xico - accessed 27 December 2019).

The urban area of Mexico City covers almost the whole northern half of Mexico City sensu lato (previously Distrito Federal) and is rapidly expanding (e.g., Hernández-Flores et al. 2017), including through illegal development (Rodríguez López et al. 2017). The southern half of Mexico City sensu lato is occupied by mountains and ravines covered by extensive forests and grasslands, some of them highly fragmented by housing developments and cultivated fields. The air pollution is such that the governments of Mexico City and the State of Mexico created a program at the end of 1989 that limits motor vehicle use in the city. However, air pollution continued to increase despite the initial restrictions, and currently there are increased limitations on vehicle use. Spaces for new residential development within the city are fewer and the population continues to grow and demand more resources, increasing the production of waste, the emission of greenhouse gases, the number of fires, the illegal occupation of protected areas, and the depletion of available natural resources (Santibáñez-Andrade et al. 2015; SEMARNAT 2016; Heider et al. 2018). Increased urbanization around Mexico City proper has also affected rivers and streams (Caro-Borrero et al. 2016). This considerable modification of the natural habitat exerts a constant pressure on the biological diversity of Mexico City. Amphibians and reptiles are strongly affected by these changes, and there are species whose presence in Mexico City is known only from their original records (e.g., Geophis bicolor and G. petersi), or whose conservation status is quite tenuous (e.g., Eleutherodactylus grandis, Rana tlaloci, Ambystoma mexicanum, and Crotalus transversus).

Herein, we present an updated list of amphibians and reptiles that inhabit Mexico City in an effort to disseminate important information about its herpetofauna to help 


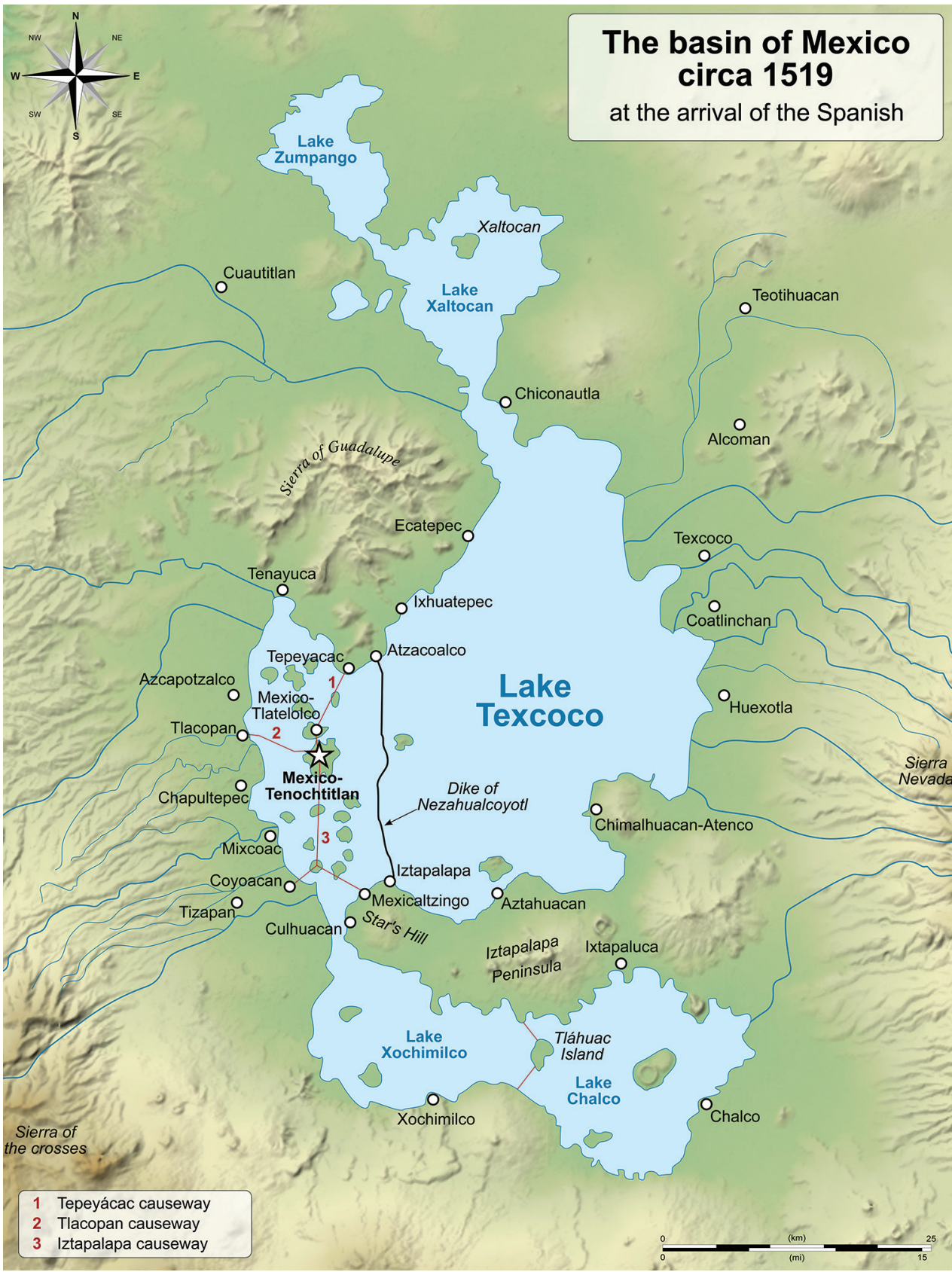

Figure I. Basin of Mexico, circa 1519. Source: https:/upload.wikimedia.org/wikipedia/commons/9/99/ Basin_of_Mexico_1519_map-en.svg

in their conservation. Previous recent efforts to catalog the herpetofauna of Mexico City reported a list of 18 species of amphibians and 39 species (one of them introduced) of reptiles from Mexico City (García-Vázquez and Méndez-de la Cruz 2016; García-Vázquez et al. 2016). 


\section{Physiographic characteristics}

Mexico City is one of 32 federal entities in Mexico. It is the capital of the country. It is located between $19^{\circ} 35^{\prime} 34^{\prime \prime} \mathrm{N}$ and $19^{\circ} 2^{\prime} 54^{\prime \prime} \mathrm{N}$, and $98^{\circ} 56^{\prime} 25^{\prime \prime} \mathrm{W}$ and $99^{\circ} 2154^{\prime} \mathrm{W}$. It is bordered by the State of Mexico to the north, east, and west, and by Morelos to the south (Fig. 2). It covers $1,485 \mathrm{~km}^{2}$, which represents $0.1 \%$ of the total area of Mexico. The urban area of Mexico City is in the Valley of Mexico, a large valley in the high plateaus in the center of Mexico, at an altitude of 2,240 m (Figs 2, 3; INEGI 2017; https://en.wikipedia.org/wiki/Mexico_City - accessed 17 December 2019).

The topography of Mexico City is highly variable, including an extensive high plateau in the northern half of the city, where the urban area sits, and mountains and volcanoes that reach up to $3,930 \mathrm{~m}$ of altitude (Volcán Ajusco) that surround the urban area mainly on its southern and western sides (Fig. 3). Mexico City is located in the physiographic province of the Neovolcanic Axis, sub-province of Lagos and Volcanes of Anahúac. Mexico City is divided into an urban development area, usually referred to as urban land ( $41 \%$ of the territory, mostly on the northern half of the city), and an ecological conservation area, referred to as conservation land (59\% of the territory, mostly on the southern half of the city). Urban land primarily consists of the urbanized plain area of the city, whereas conservation land includes areas with natural ecosystems (Reygadas-Prado 2016). Natural vegetation is primarily distributed in the conservation land, and in general terms it is represented by forests $(55.6 \%)$, ag-

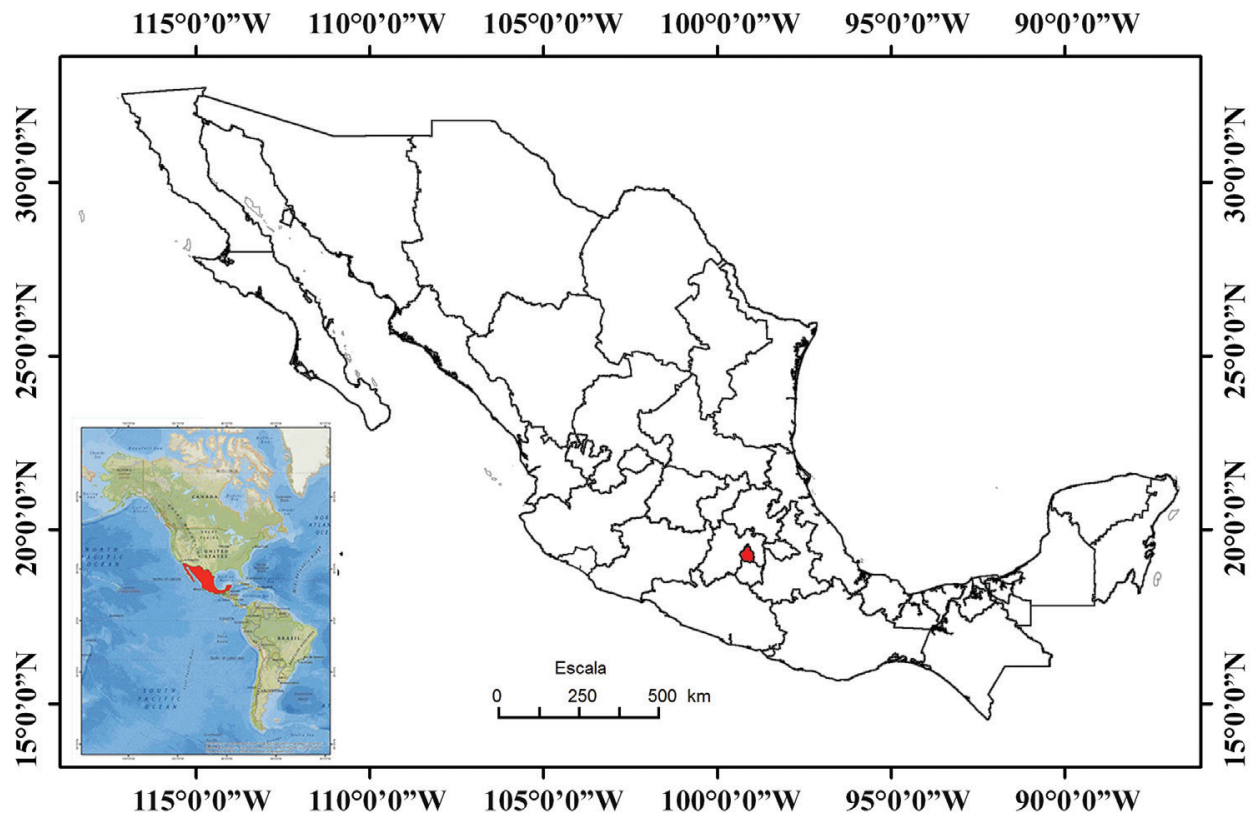

Figure 2. Map of Mexico with Mexico City shown in red (modified from INEGI 2018). 
ricultural areas (35.8\%), grasslands (7.17\%), and scrublands (1.43\%) (Fig. 4; INEGI 2017). According to the Köppen climate classification modified by García (1998), the climate of Mexico City is broadly divided into Subhumid Temperate with summer rains, covering much of the city (Fig. 5). A Semicold Subhumid climate with summer rains is present in the highest parts of the mountains that surround the city, from the west-central part running diagonally to the southeastern end on the border with Morelos; and Semiarid Temperate with summer rains present in the east-northeast end of the city, including the Sierra de Santa Catarina in the eastern part of the city and a considerable portion of the northeastern end of the city in the boroughs of Gustavo A. Madero, Venustiano Carranza, and Iztacalco (Fig. 5).

Reygadas-Prado (2016) provided a regionalization of Mexico City based on biophysical characteristics that consists of six regions. The Forests and Ravines region is made up of the largest and best-preserved forest massifs and ravines found in the south and southwest of the city, occupying an area of $532.4 \mathrm{~km}^{2}$. The principal forests in this region are oak, pine-oak, and pine forests, with some cloud forest relics in the vicinity of the Dínamos de Contreras. The Wetlands of Xochimilco and Tláhuac region is found

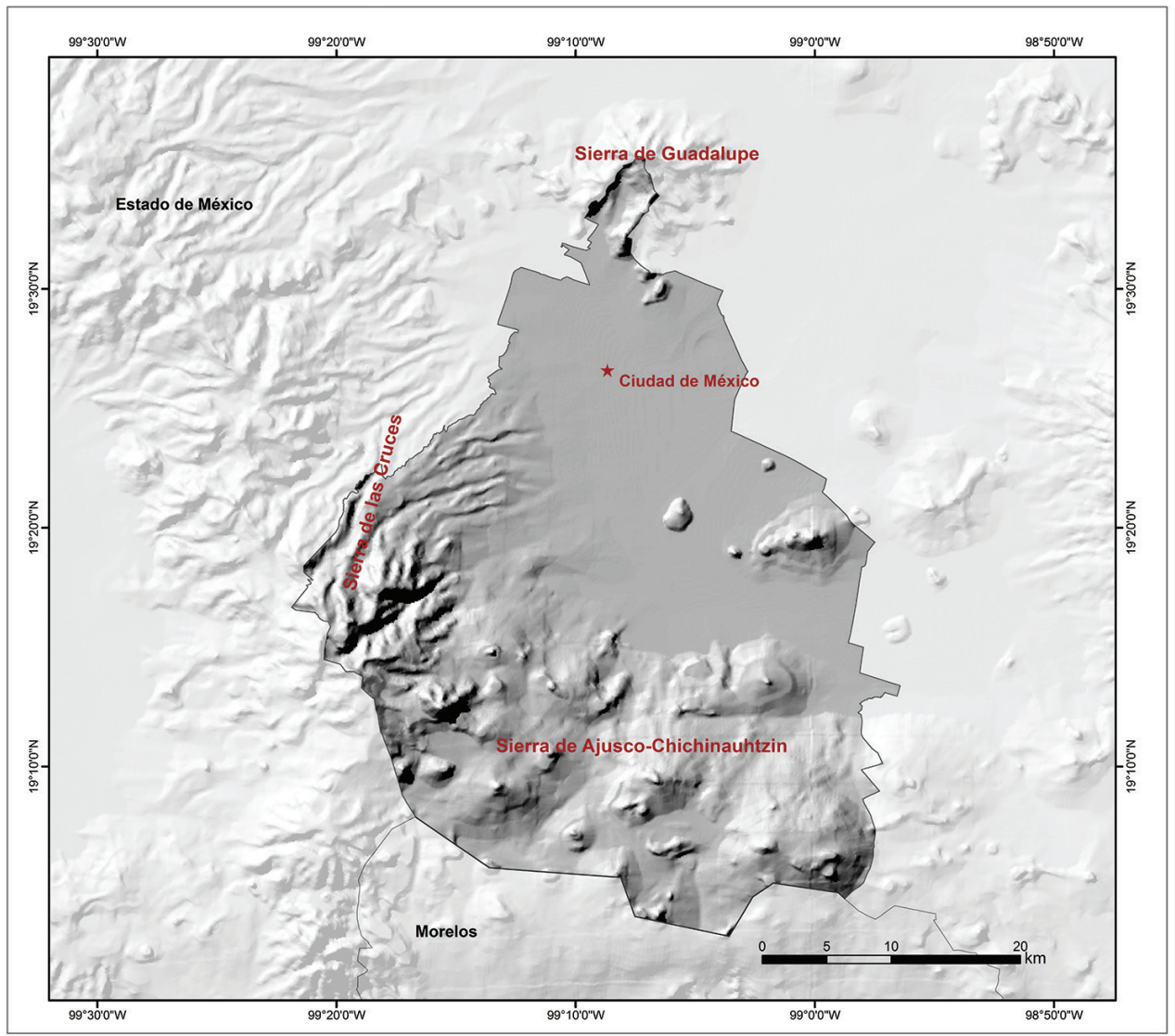

Figure 3. Topographical map of Mexico City, Mexico (Source: CONABIO 1997). 


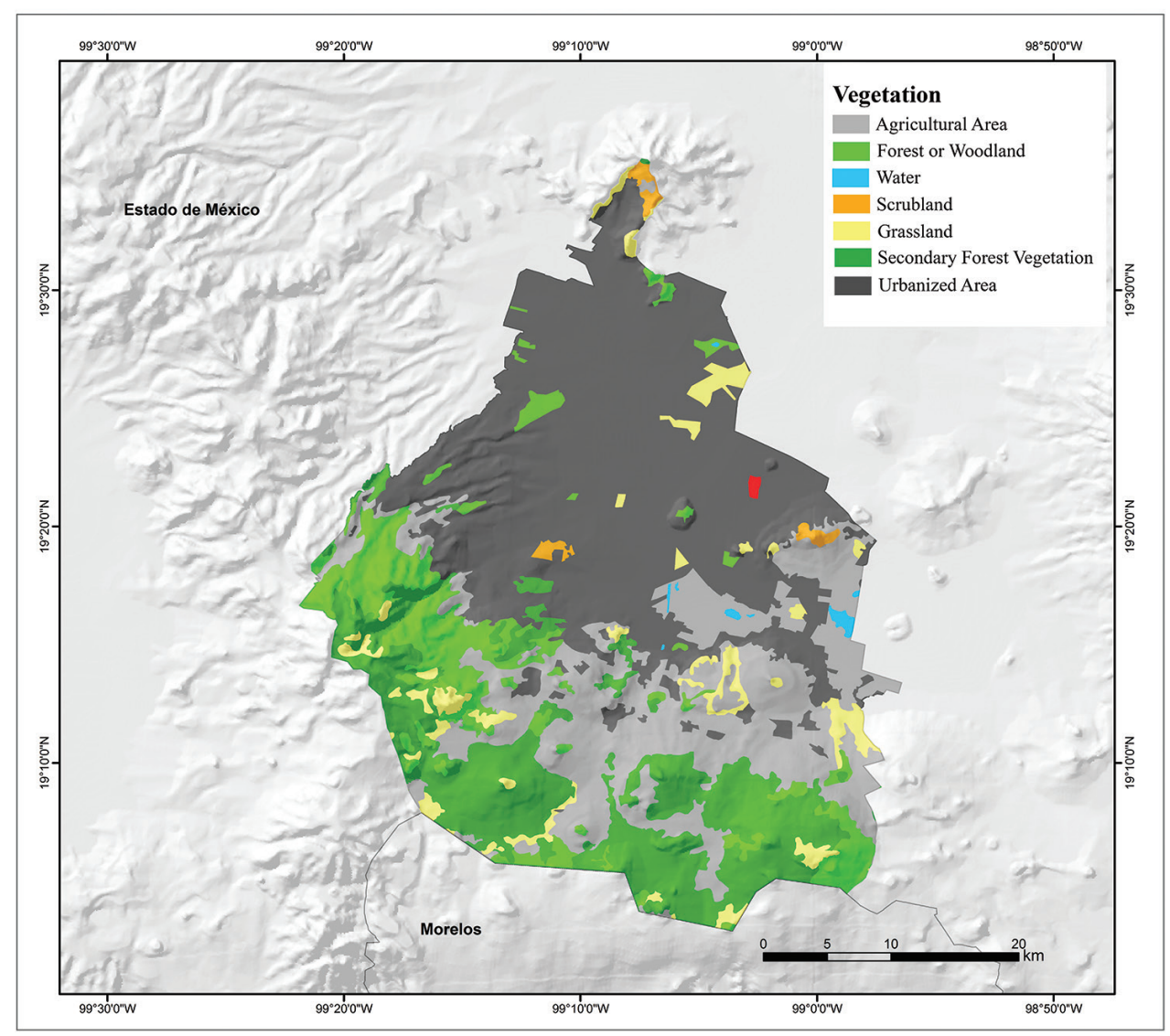

Figure 4. Vegetation map of Mexico City, Mexico (modified from Dirección General de Geografía; INEGI 2016).

in the Chinampas area of Xochimilco, San Gregorio, San Luis Tlaxialtemanco, Tláhuac and the lowlands of Tláhuac, occupying an area of $60.3 \mathrm{~km}^{2}$. This region is located in the east-central parts of the city. The Urban Parks and Gardens region includes parks, gardens, forests, protected natural areas, and areas of environmental value located on urban land, and occupies an area of $607.3 \mathrm{~km}^{2}$. It is found in the northern half of the city, except for the Sierra de Guadalupe, and two areas in the central and eastern parts of the city that represent the Sierra de Santa Catarina region. This region includes the urbanized area of Mexico City. The Mountains of Xochimilco and Milpa Alta region is found between the Urban Parks and Gardens and the Forests and Ravines regions, and it occupies an area of $237.5 \mathrm{~km}^{2}$. It runs from west-central to eastern Mexico City. It consists of an area of forests fragmented by housing developments; however, important areas of oak, pine-oak, and pine forests are located in this region. The Sierra de Guadalupe region is located in northern Mexico City and includes the protected natural areas of Sierra de Guadalupe, La Armella, and Tepeyac National Park and occupies an area of $12.9 \mathrm{~km}^{2}$. Its characteristic vegetation is xerophilous scrub. The Sierra de Santa Catarina 


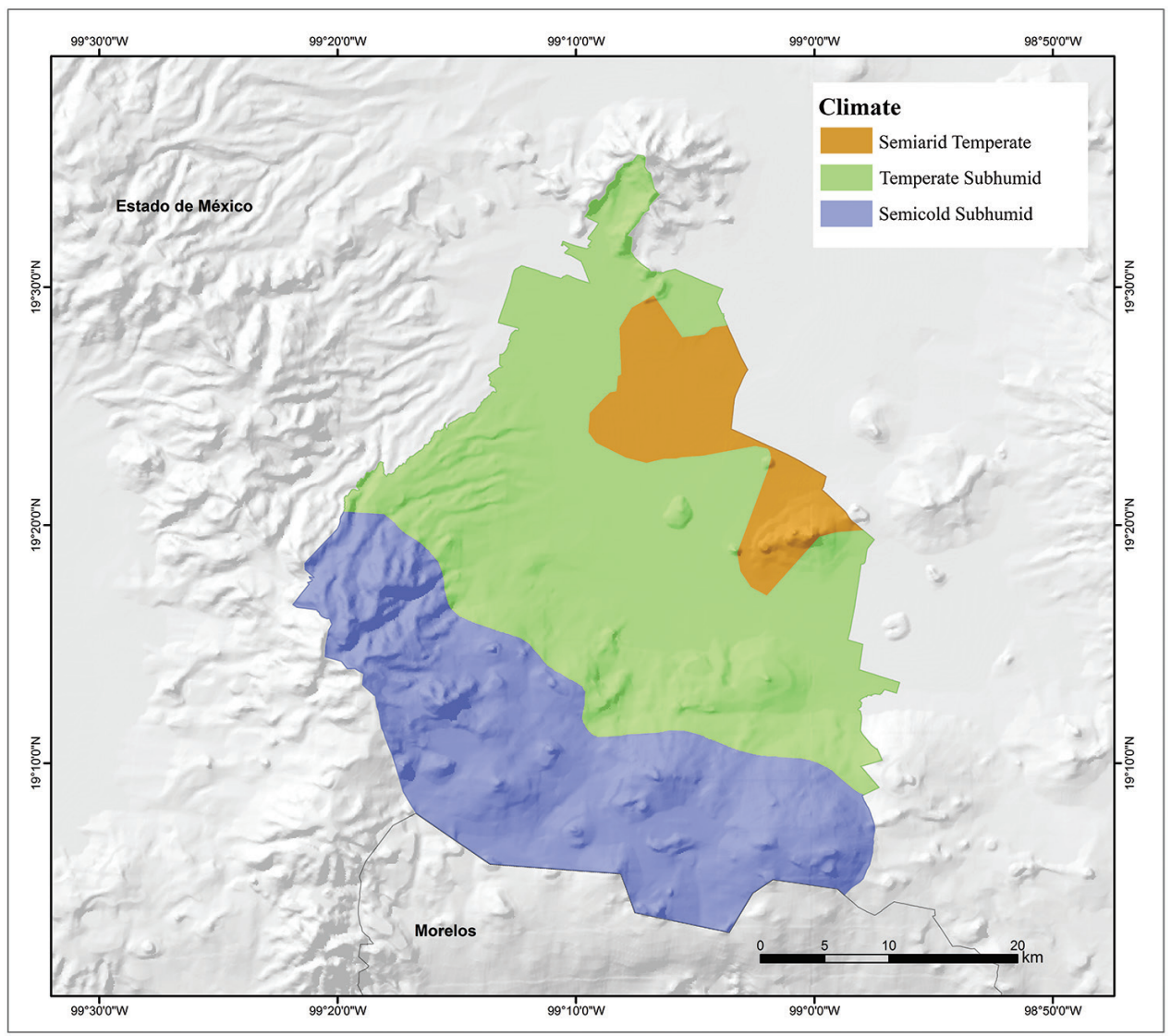

Figure 5. Climate map of Mexico City, Mexico (modified from García and Comisión Nacional para el Conocimiento y Uso de la Biodiversidad 1998).

region, located in eastern and central Mexico City, occupies an area of $31.4 \mathrm{~km}^{2}$. The vegetation here is similar to the Sierra de Guadalupe, with an important area of grassland and a greater number of tree species for reforestation (Fig. 6; Reygadas-Prado 2016).

\section{Materials and methods}

We compiled our list of amphibians and reptiles for Mexico City using our fieldwork, a thorough examination of the literature, records from VertNet.org and Servicio de Descarga de Ejemplares del Sistema Nacional de Información sobre Biodiversidad (SNIB-CONABIO): Amphibians Ciudad de México and Reptiles Ciudad de México data bases. We included species in the list if they had confirmed records, either by direct observation, literature report, or through documented museum records or vouchers. We follow Frost (2020) and AmphibiaWeb (2020) for amphibian names and Uetz and Hošek (2019) for reptile names. 


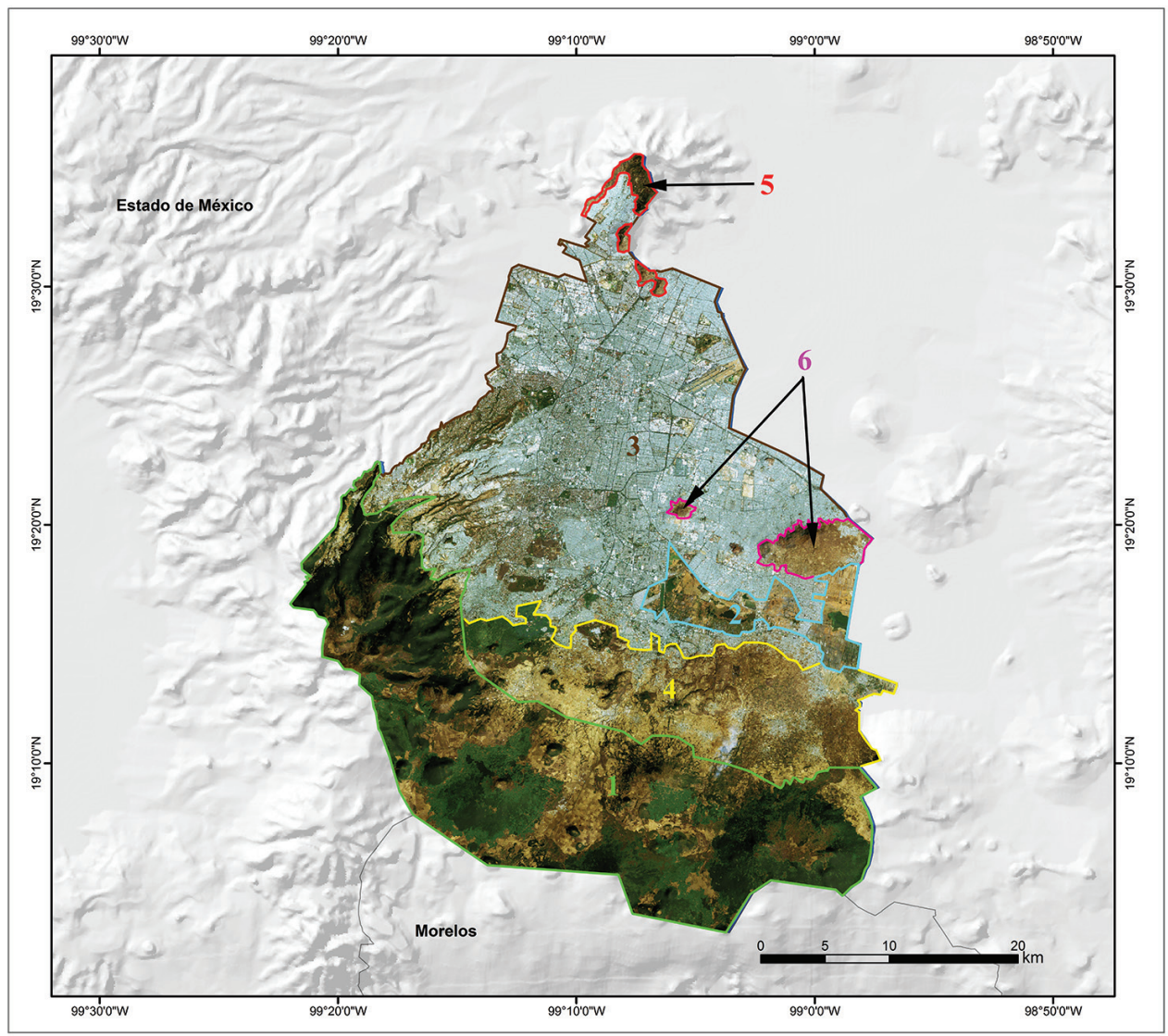

Figure 6. Satellite map showing the topographic features of Mexico City (source: Comisión Nacional para el Conocimiento y Uso de la Biodiversidad 2003) and Regions of Mexico City according to ReygadasPrado (2016): 1) Forests and Ravines; 2) Wetlands of Xochimilco and Tláhuac; 3) Urban Parks and Gardens; 4) Mountains of Xochimilco and Milpa Alta; 5) Sierra de Guadalupe; 6) Sierra de Santa Catarina.

We did not include some of the species in the Rüthling collection (AMNH) for Mexico City, as that collection includes specimens from a German School Collection, from Mexico City. These were donated to Rüthling, namely Sonora michoacanensis mutabilis Stickel, 1943 (paratypes: AMNH R-19714-6), Trimorphodon tau tau (Cope, 1870) (AMNH R-19718), Micrurus elegans elegans (Jan, 1858) (AMNH R-19720), and Thamnophis proximus (Say, 1823) (AMNH R-19809-10), but do not occur in Mexico City. In addition, some of the specimens in the German School Collection obtained by Rüthling were most likely not collected in Mexico City (Zweifel 1959). However, some of the specimens in the German School Collection donated to Rüthling could have been collected in Mexico City (e.g., Senticolis triaspis (Cope, 1866) [AMNH R-19838]), as there are two more records of this species in other collections: BMNH 1868.4.7.16 collected by Doorman and reported by Günther (1894: 115) and 
ENCB-IPN 7398 from San Gregorio, Xochimilco). Other specimens from the Rüthling collection donated by the German School are likely to occur in Mexico City (e.g., Tantilla bocourti (Günther, 1895) [AMNH R-19735]), but as no other records of the species are available, we decided not to include this species in our list.

We created species accumulation curves for the total herpetofauna, as well as amphibians and reptiles separately, using the year of the first recorded observation for each species. Such species accumulation curves likely provide a good estimate of potential herpetofaunal richness (see Raxworthy et al. 2012). In addition, we recorded the conservation status of each species based on the IUCN Red List 2019-2 (IUCN 2019), SEMARNAT (2019), and Environmental Vulnerability Scores from Wilson et al. (2013a, b) and Johnson et al. (2015). We determined the number of overlapping species with the two states that neighbor Mexico City using recent state lists (State of Mexico, Lemos-Espinal and Smith in press; Morelos, Lemos-Espinal and Smith in 2020).

\section{Results and discussion}

Mexico City harbors 65 species of amphibians and reptiles, which represent 21 families (two introduced: Typhlopidae Merrem, 1820 and Emydidae [Rafinesque, 1815]) and 33 genera (two introduced: Indotyphlops Hedges, Marion, Lipp, Marin \& Vidal, 2014 and Trachemys Agassiz, 1857) (Tables 1,2). These include 18 species of amphibians (nine anurans and nine salamanders) and 47 reptiles (14 lizards, 30 snakes [one introduced], and three turtles [one introduced]). It appears that this list of amphibian and reptile species is likely fairly complete given the shape of the species accumulation curves (Fig. 7). The species accumulation curves indicate a rapid accumulation of species in the late 1800s, followed by a slow gradual increase in species throughout the $20^{\text {th }}$ and early $21^{\text {st }}$ centuries, with a leveling off in recent years.

The two introduced species are Brahminy Blindsnake, Indotyphlops braminus (Daudin, 1803), and Huastecan Slider, Trachemys venusta (Gray, 1855). Two of the 63 native species are endemic to Mexico City: Great Piping Frog, Eleutherodactylus grandis (Dixon, 1957), and Axolotl, Ambystoma mexicanum (Shaw \& Nodder, 1798). The latter species originally inhabited lakes in the State of Mexico and Mexico City but is currently only known from the remnants of Lake Xochimichilco (Frost 2020). The most species-rich amphibian family is Plethodontidae Gray, 1850, and the most species-rich reptile family is Phrynosomatidae Fitzinger, 1843 (Table 1).

We compiled a list of eight species (six amphibians, two reptiles: Table 3) that potentially occur in Mexico City based on their distribution along the border with Morelos and the State of Mexico. We used distributional records in Vertnet.org and the Sistema Nacional de Información sobre Biodiversidad (SNIB-CONABIO) for the two neighboring states and Mexico City to generate this list. As more herpetological work is done near the borders with the neighboring states, we believe that these "likely to occur" species will be recorded for Mexico City. 


\section{General distribution}

Fifteen of the 18 species of amphibians found in Mexico City are endemic to Mexico. Two species are endemic to Mexico City (Eleutherodactylus grandis and Ambystoma mexicanum), one species has a spotty distribution in Mexico City and the State of Mexico, seven are distributed in central Mexico (Dryophytes plicatus [Brocchi, 1877], Ambystoma altamirani Dugès, 1895, Aquiloeurycea cephalica [Cope, 1865], Chiropterotriton orculus [Cope, 1865], Pseudoeurycea altamontana [Taylor, 1939], P. leprosa [Cope, 1869], and P. tlilicxitl Lara-Góngora, 2003), two are distributed in central Mexico and the Mexican Altiplano (Rana montezumae Baird, 1854, and Anaxyrus compactilis [Wiegmann, 1833]), one occurs in central Mexico, the Mexican Altiplano, the Sierra Madre Occidental, and the Sierra Madre Oriental (Dryophytes eximius [Baird, 1854]), and one occurs along the Neovolcanic Axis, the Sierra Madre Occidental, the Sierra Madre Oriental, and the Sierra Madre del Sur of Guerrero (Isthmura belli [Gray, 1850]). The three amphibian species not endemic to Mexico that inhabit Mexico City are species found in the United States and Mexico (Table 1). Twelve of the 14 species of lizards that occur in Mexico City are endemic to Mexico, six of the endemic species are restricted to a small area in the State of Mexico and Morelos and Mexico City, and in some cases the states of Puebla or Oaxaca (Sceloporus aeneus Wiegmann, 1828, S. anahuacus Lara-Góngora, 1983, S. mucronatus Cope, 1885, S. palaciosi Lara-Góngora, 1983, S. sugillatus Smith, 1942, and Plestiodon copei [Taylor, 1933]), and the other six endemics are widely distributed in the Neovolcanic Axis, including parts of the Sierra Madre Occidental, the Sierra Madre Oriental, and in some cases the Mexican Altiplano (Barisia imbricata [Wiegmann, 1828], Phrynosoma orbiculare [Linnaeus, 1758], Sceloporus scalaris Wiegmann, 1828, S. spinosus Wiegmann, 1828, S. torquatus Wiegmann, 1828, and Plestiodon brevirostris [Günther, 1860]). One of the non-endemic species ranges widely from southeastern United States, south through most of Mexico to southern Oaxaca (Sceloporus grammicus Wiegmann, 1828), and the other species ranges from central United States to Central America (Aspidoscelis gularis [Baird \& Girard, 1852]) (Table 1). Twenty-one of the 29 species of snakes that inhabit Mexico City are endemic to Mexico. Of the eight snake species not endemic to Mexico that inhabit Mexico City, five are found in Canada and/or the United States and Mexico (Diadophis punctatus [Linnaeus, 1766], Micrurus tener Baird \& Girard, 1853, Rena dulcis Baird \& Girard, 1853, Thamnophis eques (Reuss, 1834), and Crotalus molossus Baird \& Girard, 1853), one is found from Mexico to Central America (Pituophis lineaticollis [Cope, 1861]), and two range from the southern United States to Central America (Senticolis triaspis [Cope, 1866] and Thamnophis cyrtopsis [Kennicott, 1860]).

\section{Habitat types}

The most diverse region of the city is the Forests and Ravines region, which is home to 43 species (13 amphibians, 30 reptiles), which represents $70.5 \%$ of the species 
Table I. Amphibians and reptiles of Mexico City with distributional and conservation status. Region: $(1=$ Forests and Ravines; 2 = Wetlands of Xochimilco and Tláhuac; 3 = Urban Parks and Gardens; 4 = Mountains of Xochimilco and Milpa Alta; 5 = Sierra de Guadalupe; $6=$ Sierra de Santa Catarina) according to Reygadas-Prado (2016). Species with asterisk (Geophis bicolor and G. petersii), are records without a specific locality, assigned to a region that we consider the best fit, and species with a question mark (Lampropeltis polyzona and Micrurus tener) are records without a specific locality representing species with a wide range of habitat use, such that is not possible to assign them to a specific region. IUCN Status: $(\mathrm{DD}=$ Data Deficient; $\mathrm{LC}=$ Least Concern, VU = Vulnerable, NT = Near Threatened; EN = Endangered; $\mathrm{CR}=$ Critically Endangered; NE = not Evaluated) according to the IUCN Red List (The IUCN Red List of Threatened Species, Version 2019-2 (www.iucnredlist.org; accessed 29 November 2019); conservation status in Mexico according to SEMARNAT (2019): ( $\mathrm{P}=$ in danger of extinction, $\mathrm{A}=$ threatened, $\mathrm{Pr}=$ subject to special protection, NL = not listed); Environmental Vulnerability Score: (EVS - the higher the score the greater the vulnerability: low (L) vulnerability species (EVS of 3-9); medium (M) vulnerability species (EVS of 10-13); and high (H) vulnerability species (EVS of 14-20) from Wilson et al. (2013a,b) and Johnson et al. (2015); Global Distribution: 0 = Endemic to Mexico City; 1 = Endemic to Mexico; 2 = Shared between the US and Mexico; 3 = widely distributed from Mexico to Central or South America; 4 = widely distributed from the US to Central or South America; IN = introduced to Mexico City. Date in which the first record appeared; and Source of the first record.

\begin{tabular}{|c|c|c|c|c|c|c|c|}
\hline & Region & IUCN & SEMARNAT & EVS & Global & Year & Source \\
\hline \multicolumn{8}{|l|}{ Class Amphibia } \\
\hline \multicolumn{8}{|l|}{ Order Anura } \\
\hline \multicolumn{8}{|l|}{ Family Bufonidae Gray, 1825} \\
\hline $\begin{array}{l}\text { Anaxyrus compactilis (Wiegmann, } \\
1833 \text { ) }\end{array}$ & $\begin{array}{c}1,2,3 \\
4,5\end{array}$ & LC & NL & $\mathrm{H}(14)$ & 1 & 1890 & Herrera 1890 \\
\hline \multicolumn{8}{|c|}{ Family Craugastoridae Hedges, Duellman, \& Heinecker, 2008} \\
\hline Craugastor augusti (Dugès, 1879) & 5 & LC & NL & $\mathrm{L}(8)$ & 2 & 1981 & $\begin{array}{l}\text { Méndez de la } \\
\text { Cruz et al. } 1992\end{array}$ \\
\hline \multicolumn{8}{|l|}{ Family Eleutherodactylidae Lutz, 1954} \\
\hline $\begin{array}{l}\text { Eleutherodactylus grandis (Dixon, } \\
\text { 1957) }\end{array}$ & 3 & CR & $\operatorname{Pr}$ & $\mathrm{H}(18)$ & 0 & 1957 & Dixon 1957 \\
\hline \multicolumn{8}{|l|}{ Family Hylidae Rafinesque, 1815} \\
\hline Dryophytes arenicolor (Cope, 1886) & 1,3 & LC & NL & $\mathrm{L}(7)$ & 2 & 1919 & AMNH A-13254 \\
\hline Dryophytes eximius (Baird, 1854) & $\begin{array}{c}1,2,3 \\
4,5\end{array}$ & LC & NL & M (10) & 1 & 1853 & USNM 3248 \\
\hline Dryophytes plicatus (Brocchi, 1877) & 1,3 & LC & A & M (11) & 1 & 1917 & MCZ-A 17702 \\
\hline \multicolumn{8}{|l|}{ Family Ranidae Batsch, 1796} \\
\hline Rana montezumae Baird, 1854 & $2,3,4,5$ & LC & $\operatorname{Pr}$ & M (13) & 1 & 1854 & Baird 1854 \\
\hline Rana tlaloci Hillis \& Frost, 1985 & $1,2,3,5$ & $\mathrm{CR}$ & $\mathrm{P}$ & $\mathrm{H}(15)$ & 1 & 1919 & AMNH A-12214 \\
\hline \multicolumn{8}{|l|}{ Family Scaphiopodidae Cope, 1865} \\
\hline Spea multiplicata (Cope, 1863) & $1,2,3,4$ & LC & NL & L (3) & 2 & 1890 & Herrera 1890 \\
\hline \multicolumn{8}{|l|}{ Order Caudata } \\
\hline \multicolumn{8}{|l|}{ Family Ambystomatidae Gray, 1850} \\
\hline Ambystoma altamirani Dugès, 1895 & 1,3 & EN & A & M (13) & 1 & 1908 & Gadow 1908 \\
\hline $\begin{array}{l}\text { Ambystoma mexicanum (Shaw \& } \\
\text { Nodder, 1798) }\end{array}$ & 2 & CR & $\mathrm{P}$ & H (15) & 0 & 1798 & $\begin{array}{c}\text { Shaw and } \\
\text { Nodder } 1798\end{array}$ \\
\hline Ambystoma velasci Dugès, 1888 & 5 & LC & Pr & M (10) & 1 & 1882 & USNM 12721 \\
\hline \multicolumn{8}{|l|}{ Family Plethodontidae Gray, 1850} \\
\hline Aquiloeurycea cephalica (Cope, 1865) & 1,3 & NT & A & H (14) & 1 & 1941 & AMNH A-52026 \\
\hline Chiropterotriton orculus (Cope, 1865) & $1,3,4$ & $\mathrm{VU}$ & NL & H (18) & 1 & 1890 & Herrera 1890 \\
\hline Isthmura belli (Gray, 1850) & 1,3 & VU & A & M (12) & 1 & 1868 & $\begin{array}{c}\text { BMNH } \\
1868.4 .7 .37-38\end{array}$ \\
\hline
\end{tabular}




\begin{tabular}{l|c|c|c|c|c|c|c}
\hline & Region & IUCN & SEMARNAT & EVS & Global & Year & Source \\
\hline $\begin{array}{l}\text { Pseudoeurycea altamontana (Taylor, } \\
\text { 1939) }\end{array}$ & 1 & EN & Pr & H (17) & 1 & 2004 & MZFC 23438 \\
\hline Pseudoeurycea leprosa (Cope, 1869) & $1,3,4$ & LC & A & H (16) & 1 & 1890 & Herrera 1890 \\
\hline $\begin{array}{l}\text { Pseudoeurycea tlilicxitl Lara-Góngora, } \\
\text { 2003 }\end{array}$ & 1 & EN & NL & H (17) & 1 & 1979 & CNAR 3682 \\
\hline
\end{tabular}

Class Reptilia

Suborder Lacertilia

Family Anguidae Gray, 1825

\begin{tabular}{|l|c|c|c|c|c|c|c}
\hline Barisia imbricata (Wiegmann, 1828) & $\begin{array}{c}1,2,3,4, \\
5,6\end{array}$ & LC & Pr & H (14) & 1 & 1868 & $\begin{array}{c}\text { BMNH } \\
1868.4 .7 .45-47\end{array}$ \\
\hline
\end{tabular}

Family Phrynosomatidae Fitzinger, 1843

\begin{tabular}{|c|c|c|c|c|c|c|c|}
\hline $\begin{array}{l}\text { Phrynosoma orbiculare (Linnaeus, } \\
1758 \text { ) }\end{array}$ & $\begin{array}{c}1,3,4 \\
5,6\end{array}$ & LC & A & M (12) & 1 & 1818 & MVZ 43510 \\
\hline Sceloporus aeneus Wiegmann, 1828 & 1 & LC & NL & M (13) & 1 & 1918 & AMNH R-15492 \\
\hline $\begin{array}{l}\text { Sceloporus anahuacus Lara-Góngora, } \\
1983\end{array}$ & 1 & LC & NL & $\mathrm{H}(15)$ & 1 & 1976 & $\begin{array}{c}\text { Lara-Góngora } \\
1983 \\
\end{array}$ \\
\hline $\begin{array}{l}\text { Sceloporus grammicus Wiegmann, } \\
1828\end{array}$ & $\begin{array}{c}1,2,3,4 \\
5,6\end{array}$ & $\mathrm{LC}$ & $\operatorname{Pr}$ & $\mathrm{L}(9)$ & 2 & 1892 & USNM 18994 \\
\hline Sceloporus mucronatus Cope, 1885 & 1 & $\mathrm{LC}$ & NL & M (13) & 1 & 1944 & AMNH R-65701 \\
\hline $\begin{array}{l}\text { Sceloporus palaciosi Lara-Góngora, } \\
1983\end{array}$ & 1,4 & LC & NL & $\mathrm{H}(15)$ & 1 & 1979 & MZFC 790 \\
\hline Scelopours scalaris Wiegmann, 1828 & $2,3,5,6$ & $\mathrm{LC}$ & NL & $\mathrm{M}(12)$ & 1 & 1896 & USNM 46877 \\
\hline Sceloporus spinosus Wiegmann, 1828 & 5,6 & LC & NL & $\mathrm{M}(12)$ & 1 & 1882 & USNM 12720 \\
\hline Sceloporus sugillatus Smith, 1942 & 1 & LC & NL & $\mathrm{H}(16)$ & 1 & 2008 & $\begin{array}{c}\text { Mendoza- } \\
\text { Hernández et al. } \\
2008\end{array}$ \\
\hline Sceloporus torquatus Wiegmann, 1828 & $\begin{array}{c}1,2,3,4 \\
5,6\end{array}$ & LC & NL & M (11) & 1 & 1882 & USNM 12719 \\
\hline \multicolumn{8}{|l|}{ Family Scincidae Gray, 1825} \\
\hline Plestiodon brevirostris (Günther, 1860) & 1 & LC & NL & M (11) & 1 & $?$ & $\begin{array}{l}\text { FMNH w/o } \\
\text { number }\end{array}$ \\
\hline Plestiodon copei (Taylor, 1933) & 1 & LC & $\operatorname{Pr}$ & $\mathrm{H}(14)$ & 1 & 1958 & ENCB 810 \\
\hline \multicolumn{8}{|l|}{ Family Teiidae Gray, 1827} \\
\hline $\begin{array}{l}\text { Aspidoscelis gularis (Baird \& Girard, } \\
1852 \text { ) }\end{array}$ & $4,5,6$ & LC & NL & $\mathrm{L}(9)$ & 4 & 1919 & AMNH R-14221 \\
\hline \multicolumn{8}{|l|}{ Suborder Serpentes } \\
\hline \multicolumn{8}{|l|}{ Family Colubridae Oppel, 1811} \\
\hline $\begin{array}{l}\text { Conopsis biserialis (Taylor \& Smith, } \\
1942 \text { ) }\end{array}$ & 3 & LC & A & $\mathrm{M}(13)$ & 1 & 1960 & ENCB 124 \\
\hline Conopsis lineata (Kennicott, 1859) & $1,3,4$ & LC & NL & M (13) & 1 & 1890 & Herrera 1890 \\
\hline Conopsis nasus (Günther, 1858) & 3,5 & LC & NL & $\mathrm{M}(11)$ & 1 & 1903 & $\begin{array}{c}\text { BMNH } \\
1903.9 .30 .200 \\
\end{array}$ \\
\hline Lampropeltis polyzona Cope, 1860 & $?$ & LC & NL & $\mathrm{L}(7)$ & 1 & 1868 & $\begin{array}{c}\text { BMNH } \\
1868.4 .7 .4 \\
\end{array}$ \\
\hline Pituophis deppei (Dumeril, 1853) & $\begin{array}{c}1,2,3,4 \\
5,6\end{array}$ & LC & A & $\mathrm{H}(14)$ & 1 & 1868 & $\begin{array}{c}\text { BMNH } \\
1868.4 .7 .38\end{array}$ \\
\hline Pituophis lineaticollis (Cope, 1861) & 1 & LC & NL & $\mathrm{L}(8)$ & 3 & 1932 & FMNH 106582 \\
\hline Salvadora bairdi Jan \& Sordelli, 1860 & $1,3,5,6$ & $\mathrm{LC}$ & $\operatorname{Pr}$ & $\mathrm{H}(15)$ & 1 & 1919 & AMNH R-19528 \\
\hline Senticolis triaspis (Cope, 1866) & 2 & LC & NL & $\mathrm{L}(6)$ & 4 & 1868 & $\begin{array}{c}\text { BMNH } \\
1868.4 .7 .16 \\
\end{array}$ \\
\hline Tantilla calamarina Cope, 1866 & 1 & LC & $\operatorname{Pr}$ & $\mathrm{M}(12)$ & 1 & 1919 & AMNH R-19750 \\
\hline \multicolumn{8}{|l|}{ Family Dipsadidae Bonaparte, 1838} \\
\hline Diadophis punctatus (Linnaeus, 1766) & $1,2,3,5$ & LC & NL & $\mathrm{L}(4)$ & 2 & 1868 & Günther 1868 \\
\hline Geophis bicolor Günther, 1868 & $1^{*}$ & $\mathrm{DD}$ & $\operatorname{Pr}$ & $\mathrm{H}(15)$ & 1 & 1868 & Günther 1868 \\
\hline
\end{tabular}




\begin{tabular}{|c|c|c|c|c|c|c|c|}
\hline & Region & IUCN & SEMARNAT & EVS & Global & Year & Source \\
\hline Geophis petersii Boulenger, 1894 & $1^{*}$ & DD & \begin{tabular}{|c|}
$\operatorname{Pr}$ \\
\end{tabular} & $\mathrm{H}(15)$ & 1 & 1894 & Boulenger 1894 \\
\hline Rhadinaea laureata (Günther, 1868) & $1,3,6$ & LC & NL & M (12) & 1 & 1868 & Günther 1868 \\
\hline Rhadinaea taeniata (Peters, 1863) & 1 & LC & NL & M (13) & 1 & 1868 & $\begin{array}{c}\text { BMNH } \\
1868.4 .7 .13-14\end{array}$ \\
\hline \multicolumn{8}{|l|}{ Family Elapidae Boie, 1827} \\
\hline Micrurus tener Baird \& Girard, 1853 & $?$ & LC & NL & M (11) & 2 & 1868 & $\begin{array}{c}\text { BMNH } \\
1868.4 .7 .5\end{array}$ \\
\hline \multicolumn{8}{|c|}{ Family Leptotyphlopidae Stejneger, 1892} \\
\hline Rena dulcis Baird \& Girard, 1853 & 3 & LC & NL & M (13) & 2 & 2009 & $\begin{array}{c}\text { Méndez de la } \\
\text { Cruz et al. } 2009\end{array}$ \\
\hline \multicolumn{8}{|l|}{ Family Natricidae Bonaparte, 1838} \\
\hline Storeria storerioides (Cope, 1866) & $1,3,4$ & LC & NL & $\mathrm{M}(11)$ & 1 & 1868 & $\begin{array}{c}\text { BMNH } \\
1868.4 .7 .15\end{array}$ \\
\hline $\begin{array}{l}\text { Thamnophis cyrtopsis (Kennicott, } \\
\text { 1860) }\end{array}$ & 1 & LC & A & $\mathrm{L}(7)$ & 4 & 1890 & Herrera 1890 \\
\hline Thamnophis eques (Reuss, 1834) & $1,3,5,6$ & LC & A & $\mathrm{L}(8)$ & 2 & 1860 & Kennicott 1860 \\
\hline $\begin{array}{l}\text { Thamnophis melanogaster (Wiegmann, } \\
1830 \text { ) }\end{array}$ & 2,3 & EN & A & $\mathrm{H}(15)$ & 1 & 1882 & USNM 12726 \\
\hline Thamnophis pulchrilatus (Cope, 1885) & 1 & LC & NL & $\mathrm{H}(15)$ & 1 & 1890 & Herrera 1890 \\
\hline Thamnophis scalaris Cope, 1861 & $1,3,5$ & LC & A & $\mathrm{H}(14)$ & 1 & 1890 & Herrera 1890 \\
\hline Thamnohis scaliger (Jan, 1863) & $1,2,3,4$ & VU & A & $\mathrm{H}(15)$ & 1 & 1868 & $\begin{array}{c}\text { BMNH } \\
1868.4 .7 .10\end{array}$ \\
\hline \multicolumn{8}{|l|}{ Family Typhlopidae Merrem, 1820} \\
\hline $\begin{array}{l}\text { Indotyphlops braminus (Daudin, } \\
\text { 1803) }\end{array}$ & 3 & IN & NA & NA & NA & 1995 & CNAR 11281 \\
\hline \multicolumn{8}{|l|}{ Family Viperidae Oppel, 1811} \\
\hline Crotalus aquilus Klauber, 1952 & 5 & LC & $\operatorname{Pr}$ & $\mathrm{H}(16)$ & 1 & 2016 & $\begin{array}{c}\text { García-Vázquez } \\
\text { and Méndez de la } \\
\text { Cruz } 2016\end{array}$ \\
\hline $\begin{array}{l}\text { Crotalus molossus Baird \& Girard, } \\
1853\end{array}$ & $3,4,5,6$ & LC & $\operatorname{Pr}$ & $\mathrm{L}(8)$ & 2 & 1868 & $\begin{array}{c}\text { BMNH } \\
1868.4 .7 .2\end{array}$ \\
\hline Crotalus polystictus (Cope, 1865) & 2 & LC & $\operatorname{Pr}$ & $\mathrm{H}(16)$ & 1 & 1890 & Herrera 1890 \\
\hline Crotalus ravus Cope, 1865 & $\begin{array}{l}1,2,3,4 \\
5,6\end{array}$ & LC & A & $\mathrm{H}(14)$ & 1 & 1944 & UMMZ 99847 \\
\hline Crotalus transversus Taylor, 1944 & 1 & LC & $\mathrm{P}$ & $\mathrm{H}(17)$ & 1 & $?$ & ROM 47094 \\
\hline Crotalus triseriatus (Wagler, 1830) & $1,2,3,4$ & LC & NL & $\mathrm{H}(16)$ & 1 & 1868 & $\begin{array}{c}\text { BMNH } \\
1946.1 .17 .70\end{array}$ \\
\hline \multicolumn{8}{|l|}{ Order Testudines } \\
\hline \multicolumn{8}{|l|}{ Family Emydidae (Rafinesque, 1815) } \\
\hline Trachemys venusta (Gray, 1855) & 3 & IN & NA & NA & NA & 2009 & $\begin{array}{c}\text { Méndez de la } \\
\text { Cruz et al. } 2009\end{array}$ \\
\hline \multicolumn{8}{|l|}{ Family Kinosternidae Agassiz, 1857} \\
\hline Kinosternon hirtipes (Wagler, 1830) & 2,5 & $\mathrm{LC}$ & $\operatorname{Pr}$ & $\mathrm{M}(10)$ & 2 & 1888 & Dugès 1888 \\
\hline Kinosternon integrum LeConte, 1854 & 2 & LC & $\operatorname{Pr}$ & M (11) & 1 & 1888 & Dugès 1888 \\
\hline
\end{tabular}

pool for the city. This region occupies the second place in the territorial area of the city with $534.4 \mathrm{~km}^{2}$ (36.0\% of the surface of Mexico City). This region is in the best conservation state and is where there is the possibility of rediscovering species known only from historical records such as Geophis bicolor Günther, 1868, Geophis petersii Boulenger, 1894, and Rhadinaea taeniata (Peters, 1863), or finding new species records such as for Eleutherodactylus nitidus (Peters, 1870), Exerodonta smaragdina (Tay- 
lor, 1940), and Tantilla bocourti (Günther, 1895). This region also has a high number of species listed in an IUCN protected category (7 amphibians, 1 reptile), listed in a SEMARNAT protected category (6 amphibians, 7 reptiles), and categorized as high risk by the EVS (7 amphibians, 15 reptiles). The second most diverse region of Mexico City is the Urban Parks and Gardens that hosts 34 species (13 amphibians, 21 reptiles). This region occupies the largest area of the city with $607.3 \mathrm{~km}^{2}(40.9 \%$ of the surface of Mexico City). It is also the most populated region and is dominated by urban habitats, which are generally not suitable for most amphibians and reptiles. However, it has two important urban parks, the Pedregal de San Angel Ecological Reserve (REPSA) and the Chapultepec Forest, where the largest number of species has been recorded for this region. The number of species in this region listed in an IUCN protected category ( 6 amphibians, 2 reptiles), listed as protected by SEMARNAT (6 amphibians, 7 reptiles), and categorized as high risk by the EVS (6 amphibians, 8 reptiles) is also high. The Wetlands of Xochimilco and Tláhuac and the Mountains of Xochimilco and Milpa Alta, and the Sierra de Guadalupe host similar numbers of amphibian and reptile species and also have similar numbers of species included in the IUCN and SEMARNAT lists or categorized as high risk by the EVS. In the Wetlands of Xochimilco and Tláhuac, 20 species (6 amphibians, 14 reptiles) are present, of which four are listed by the IUCN, five by SEMARNAT, and 10 are categorized as high risk by the EVS. In the Mountains of Xochimilco and Milpa Alta, 19 species (6 amphibians, 13 reptiles) are found, of which two are listed by the IUCN, four by SEMARNAT, and nine are categorized as high risk by the EVS. In the Sierra de Guadalupe, 23 species (6 amphibians, 17 reptiles) occur, of which one is listed by the IUCN, five by SEMARNAT, and eight are categorized as high risk by the EVS. The Sierra de Santa Catarina region is like an island, a mountain with disturbed vegetation surrounded by urban habitats. It has an area of only $31.4 \mathrm{~km}^{2}(2.1 \%$ of the area of Mexico City; Fig. 7) and harbors 13 species of reptiles. However, the government of Mexico City mentioned the presence of two amphibians and 14 reptiles, with only eight reptile species included in the SEMARNAT list (Gobierno del Distrito Federal [= Mexico City $]$ 2005). None of the reptile species in this region are included in the IUCN list, three are in the SEMARNAT list, and four are categorized as high risk by the EVS. Our observations of the distribution of amphibians and reptiles in Mexico City are broadly consistent with the findings of García Vázquez and Méndez de la Cruz (2016) and García Vázquez et al. (2016).

\section{Conservation status}

Eleven of the 63 species (17.5\%) of amphibians and reptiles in Mexico City are included in the IUCN Red List (i.e., Vulnerable, Near Threatened, or Endangered), 17 $(27.0 \%)$ are placed in a protected category (excluding NL and Pr, this last category is equivalent to the LC category of IUCN) by SEMARNAT, and 27 species $(42.9 \%)$ are categorized as high risk by the EVS (Fig. 8; Table 2). For amphibians, 38.9\% (7 of 18 species) are included in the IUCN Red List and are protected by SEMARNAT, and 


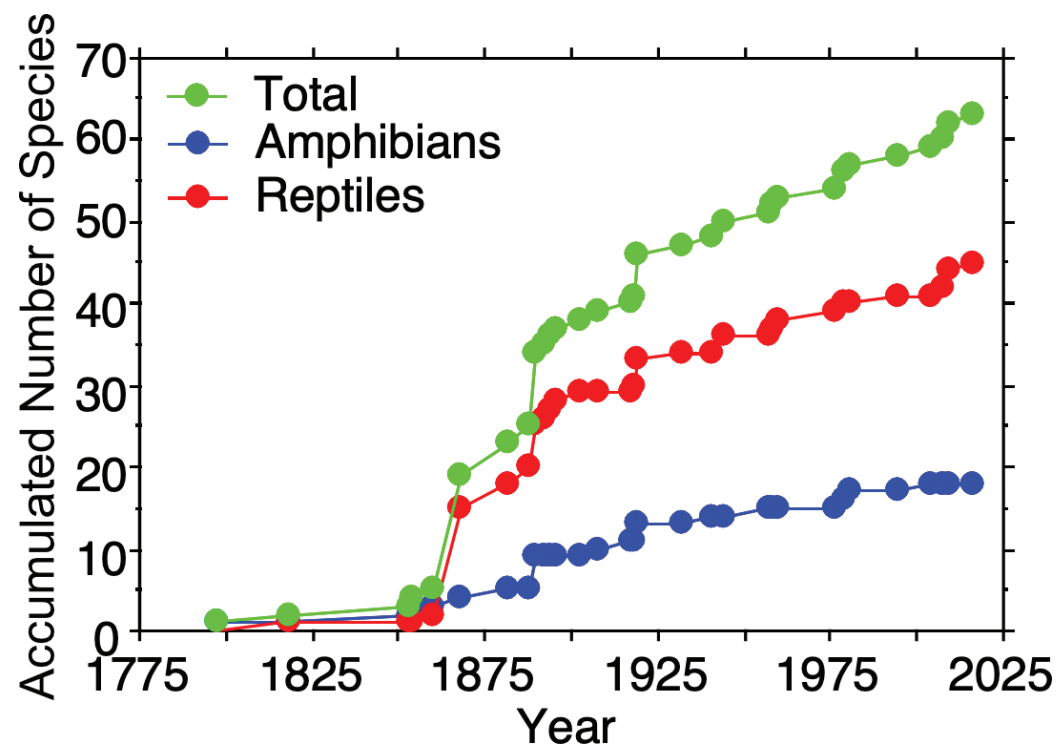

Figure 7. Species accumulation curves for total herpetofauna of Mexico City, Mexico, as well as separately for amphibians and reptiles.

A) Amphibians

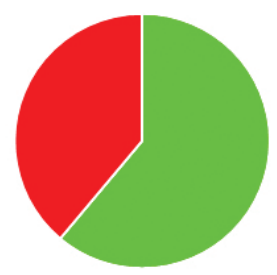

$\operatorname{IUCN}(\mathbf{N}=\mathbf{1 8})$

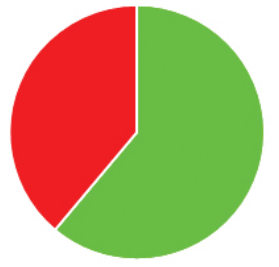

SEMARNAT $(\mathbf{N}=\mathbf{1 8})$

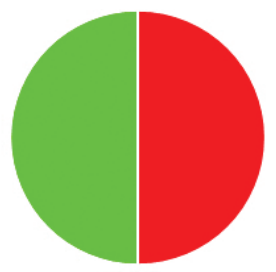

$\operatorname{EVS}(\mathbf{N}=18)$

B) Reptiles

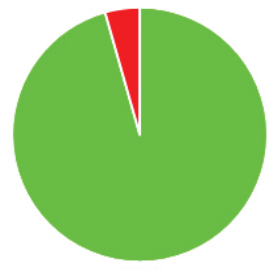

IUCN $(N=45)$

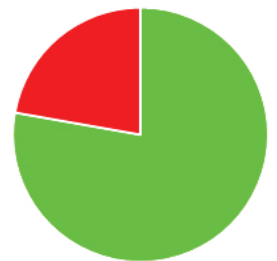

SEMARNAT $(\mathbf{N}=45)$

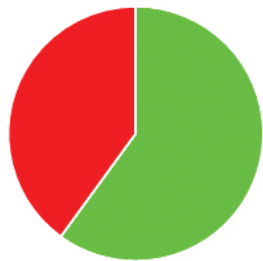

$\operatorname{EVS}(\mathbf{N}=45)$

Figure 8. Percentage of species included in the IUCN Red List or listed by SEMARNAT, and the Environmental Vulnerability Score (EVS). A Amphibians B reptiles. Green is percentage in Data Deficient and Least Concern (IUCN); Not Listed and Subject to Special Protection (we regarded the category of Subject to Special Protection in SEMARNAT equivalent to IUCN's Least Concern) (SEMARNAT); low and medium EVS. Red is percentage in protected categories or high EVS. $N$ is the number of species assessed by each agency. 
Table 2. Summary of native species present in Mexico City by class, family, order, and suborder. Status summary indicates the number of species found in each IUCN conservation status in the order DD, LC, VU, NT, EN, CR (see Table 1 for abbreviations). For mean EVS (Environmental Vulnerability Score), scores $\geq 14$ are considered to have high vulnerability (Wilson et al. 2013a, b). Conservation status in Mexico are number of species in each category (NL, Pr, A, P; see Table 1 for abbreviations) according to SEMARNAT (2019).

\begin{tabular}{|c|c|c|c|c|c|}
\hline Scientific name & genera & species & IUCN & $\overline{\mathbf{x}}$ EVS & SEMARNAT \\
\hline Class Amphibia & & & DD, LC, VU, NT, EN, CR & & NL, Pr, A, P \\
\hline Order Anura & 6 & 9 & $0,7,0,0,0,2$ & 11 & $5,2,1,1$ \\
\hline Bufonidae & 1 & 1 & $0,1,0,0,0,0$ & 14 & $1,0,0,0$ \\
\hline Craugastoridae & 1 & 1 & $0,1,0,0,0,0$ & 8 & $1,0,0,0$ \\
\hline Eleutherodactylidae & 1 & 1 & $0,0,0,0,0,1$ & 18 & $0,1,0,0$ \\
\hline Hylidae & 1 & 3 & $0,3,0,0,0,0$ & 9.3 & $2,0,1,0$ \\
\hline Ranidae & 1 & 2 & $0,1,0,0,0,1$ & 14 & $0,1,0,1$ \\
\hline Scaphiopodidae & 1 & 1 & $0,1,0,0,0,0$ & 3 & $1,0,0,0$ \\
\hline Order Caudata & 5 & 9 & $0,2,2,1,3,1$ & 14.7 & $2,2,4,1$ \\
\hline Ambystomatidae & 1 & 3 & $0,1,0,0,1,1$ & 12.7 & $0,1,1,1$ \\
\hline Plethodontidae & 4 & 6 & $0,1,2,1,2,0$ & 15.7 & $2,1,3,0$ \\
\hline Subtotal & 11 & 18 & $0,9,2,1,3,3$ & 12.8 & $7,4,5,2$ \\
\hline \multicolumn{6}{|l|}{ Class Reptilia } \\
\hline Order Squamata & 19 & 43 & $2,39,1,0,1,0$ & 12.3 & $23,10,9,1$ \\
\hline Suborder Lacertilia & 5 & 14 & $0,14,0,0,0,0$ & 12.6 & $10,3,1,0$ \\
\hline Anguidae & 1 & 1 & $0,1,0,0,0,0$ & 14 & $0,1,0,0$ \\
\hline Phrynosomatidae & 2 & 10 & $0,10,0,0,0,0$ & 12.8 & $8,1,1,0$ \\
\hline Scincidae & 1 & 2 & $0,2,0,0,0,0$ & 12.5 & $1,1,0,0$ \\
\hline Teiidae & 1 & 1 & $0,1,0,0,0,0$ & 9 & $1,0,0,0$ \\
\hline Suborder Serpentes & 14 & 29 & $2,25,1,0,1,0$ & 12.2 & $13,7,8,1$ \\
\hline Colubridae & 6 & 9 & $0,9,0,0,0,0$ & 11 & $5,2,2,0$ \\
\hline Dipsadidae & 3 & 5 & $2,3,0,0,0,0$ & 11.8 & $3,2,0,0$ \\
\hline Elapidae & 1 & 1 & $0,1,0,0,0,0$ & 11 & $1,0,0,0$ \\
\hline Leptotyphlopidae & 1 & 1 & $0,1,0,0,0,0$ & 13 & $1,0,0,0$ \\
\hline Natricidae & 2 & 7 & $0,5,1,0,1,0$ & 12.1 & $2,0,5,0$ \\
\hline Viperidae & 1 & 6 & $0,6,0,0,0,0$ & 14.5 & $1,3,1,1$ \\
\hline Order Testudines & 1 & 2 & $0,2,0,0,0,0$ & 10.5 & $0,2,0,0$ \\
\hline Kinosternidae & 1 & 2 & $0,2,0,0,0,0$ & 10.5 & $0,2,0,0$ \\
\hline Subtotal & 20 & 45 & $2,41,1,0,1,0$ & 12.2 & $23,12,9,1$ \\
\hline Total & 31 & 63 & $2,50,3,1,4,3$ & 12.4 & $30,16,14,3$ \\
\hline
\end{tabular}

$50.0 \%$ (9 species) are at high risk according to the EVS (Fig. 8; Table 2). For reptiles, $4.4 \%$ ( 2 of 45 species) are listed by the IUCN, 22.2\% (10 species) are protected by SEMARNAT, and 40.0\% (18 species) are at high risk according to the EVS (Fig. 8; Table 2). These results suggest that the amphibians of Mexico City are considered to be of relatively high conservation concern at a global and national scale (IUCN and SEMARNAT lists), but there are even greater conservation concerns based on the EVS. The limited distribution of half of the amphibian species that inhabit Mexico City, coupled with the loss of available habitat, places them in a delicate conservation status. For example, the Axolotl, Ambystoma mexicanum, which is listed as Critically Endangered by the IUCN and In Danger of Extinction by SEMARNAT, currently appears to be limited to Lake Xochimilco and faces threats such as introduced predators, illegal 
Table 3. List of amphibian and reptile species that potentially occur in Mexico City.

\begin{tabular}{ll}
\hline \multicolumn{1}{c}{ Taxon } & Likely to occur in: \\
\hline Class Amphibia & \\
Order Anura & \\
Family Bufonidae & southern Mexico City \\
Incilius marmoreus (Wiegmann, 1833) & southern Mexico City \\
Incilius occidentalis (Camerano, 1879) & \\
Family Eleutherodactylidae & southern Mexico City \\
Eleutherodactylus nitidus (Peters, 1870) & \\
Family Hylidae & southern Mexico City \\
Exerodonta smaragdina (Taylor, 1940) & southern Mexico City \\
Tlalocohyla smithii (Boulenger, 1902) & \\
Family Ranidae & southern Mexico City \\
Rana spectabilis Hillis \& Frost, 1985 & \\
Class Reptilia & \\
Order Squamata & \\
Suborder Lacertilia & \\
Family Scincidae & \\
Plestiodon indubitus (Taylor, 1933) & southern Mexico City \\
Suborder Serpentes & \\
Family Colubridae & \\
Tantilla bocourti (Günther, 1895) & southern Mexico City \\
\hline
\end{tabular}

collection, and pollution (Griffiths et al. 2004; Contreras et al. 2009; Recuero et al. 2010). On the other hand, reptiles are of lesser conservation concern than amphibians according to the IUCN and SEMARNAT lists, but not the EVS list (Fig. 8), which is a reflections that EVS uses more variables in determining country-level conservation status than either the IUCN or SEMARNAT (see Wilson et al. 2013a, 2013b).

\section{Comparison with neighboring states}

Mexico City shares more than $90 \%$ of its species (59 of 63 species $=93.7 \%$, Table 4), with the State of Mexico, such that the herpetofauna of Mexico City is practically contained in that of the State of Mexico. Both the city and state are in the Basin of Mexico, which is included in the physiographic province of the Neovolcanic Axis, and all of Mexico City belongs to the sub-province of Lagos y Volcanes de Anáhuac, which also forms a part of the State of Mexico. Thus, the topographic and physiographic characteristics shared by these two entities result in a great similarity of their biological diversity, including their herpetofaunas. Additionally, the State of Mexico surrounds Mexico City on three sides (west, north, and east), and this, coupled with the small territorial area of Mexico City, results in a nesting of the species richness of Mexico City in the species richness of the State of Mexico. There are four species that Mexico City does not share with the State of Mexico. These include Eleutherodactylus grandis, which is limited to the Pedregal de San Angel in the Urban Parks and Gardens region; Ambystoma mexicanum, currently limited to two wild populations, one in the channels 
Table 4. Summary of the numbers of species shared between Mexico City and neighboring Mexican states (not including introduced species). The percent of Mexico City species shared by a neighboring state are given in parentheses. Total refers to the total number of species found in Mexico City and two neighboring states (i.e., regional species pool) and the number in parentheses in this column is the percent of the regional species pool found in Mexico City. - indicates either Mexico City or the neighboring state has no species in the taxonomic group, or none of that specific taxon is shared between the states, thus no value for shared species is provided.

\begin{tabular}{|c|c|c|c|c|}
\hline Taxon & Mexico City & State of Mexico & Morelos & Total \\
\hline Class Amphibia & 18 & $16(88.9)$ & $14(77.8)$ & $55(32.7)$ \\
\hline Order Anura & 9 & $8(88.9)$ & $7(77.8)$ & $39(23.1)$ \\
\hline Bufonidae & 1 & $1(100)$ & $1(100)$ & $5(20.0)$ \\
\hline Centrolenidae & - & - & - & $1(0)$ \\
\hline Craugastoridae & 1 & $1(100)$ & $1(100)$ & $5(20.0)$ \\
\hline Eleutherodactylidae & 1 & - & - & $5(20.0)$ \\
\hline Hylidae & 3 & $3(100)$ & $3(100)$ & $10(30.0)$ \\
\hline Leptodactylidae & - & - & - & $1(0)$ \\
\hline Microhylidae & - & - & - & $3(0)$ \\
\hline Phyllomedusidae & - & - & - & $1(0)$ \\
\hline Ranidae & 2 & $2(100)$ & $1(50)$ & $7(28.6)$ \\
\hline Scaphiopodidae & 1 & $1(100)$ & $1(100)$ & $1(100)$ \\
\hline Order Caudata & 9 & $8(88.9)$ & $7(77.8)$ & $16(56.3)$ \\
\hline Ambystomatidae & 3 & $2(66.7)$ & $1(33.3)$ & $8(37.5)$ \\
\hline Plethodontidae & 6 & $6(100)$ & $6(100)$ & $8(75.0)$ \\
\hline Class Reptilia & 45 & $43(95.6)$ & $35(77.8)$ & $125(36.0)$ \\
\hline Order Squamata & 43 & $41(95.3)$ & $33(76.7)$ & $120(35.8)$ \\
\hline Suborder Lacertilia & 14 & $14(100)$ & $12(85.7)$ & 49 (28.6) \\
\hline Anguidae & 1 & $1(100)$ & $1(100)$ & $5(20.0)$ \\
\hline Dactyloidae & - & - & - & $1(0)$ \\
\hline Eublepharidae & - & - & - & $1(0)$ \\
\hline Helodermatidae & - & - & - & $1(0)$ \\
\hline Iguanidae & - & - & - & $1(0)$ \\
\hline Phrynosomatidae & 10 & $10(100)$ & $9(90.0)$ & $23(43.5)$ \\
\hline Phyllodactylidae & - & - & - & $3(0)$ \\
\hline Scincidae & 2 & $2(100)$ & $2(100)$ & $6(33.3)$ \\
\hline Teiidae & 1 & $1(100)$ & - & $8(12.5)$ \\
\hline Suborder Serpentes & 29 & $27(93.1)$ & $21(72.4)$ & $71(40.8)$ \\
\hline Boidae & - & - & - & $1(0)$ \\
\hline Colubridae & 9 & $9(100)$ & $9(100)$ & $24(37.5)$ \\
\hline Dipsadidae & 5 & $4(80.0)$ & $2(40.0)$ & $18(27.8)$ \\
\hline Elapidae & 1 & $1(100)$ & $1(100)$ & $3(33.3)$ \\
\hline Leptotyphlopidae & 1 & - & - & $3(33.3)$ \\
\hline Loxocemidae & - & - & - & $1(0)$ \\
\hline Natricidae & 7 & $7(100)$ & $4(57.1)$ & $10(70.0)$ \\
\hline Viperidae & 6 & $6(100)$ & $5(83.3)$ & $11(54.5)$ \\
\hline Order Testudines & 2 & $2(100)$ & $2(100)$ & $5(40.0)$ \\
\hline Emydidae & - & - & - & $1(0)$ \\
\hline Geoemydidae & - & - & - & $1(0)$ \\
\hline Kinosternidae & 2 & $2(100)$ & $2(100)$ & $3(66.7)$ \\
\hline Total & 63 & $59(93.7)$ & $49(77.8)$ & $180(35.0)$ \\
\hline
\end{tabular}


of Lake Xochimilco and a second in the remnants of Lake Chalco, both in southern Mexico City, where it faces serious conservation problems (Zambrano González et al. 2003; Recuero et al. 2010); Geophis petersi, a snake with secretive habits, which is difficult to find and known only from the type series; and Rena dulcis, reported by Méndez de la Cruz et al. $(2007,2009)$ in the Pedregal de San Angel.

Geophis petersi was collected by H. Doorman in 1868 and its type locality at Mexico City was questioned and restricted to Pátzcuaro, Michoacán by Smith and Taylor (1950); however, Downs (1967) pointed out that this restriction was unjustified and that the presence of $G$. petersi at the southern tip of the Mexican Altiplano seems reasonable. Due to the secretive habits and presence of similar habitats in the State of Mexico, it is possible that $G$. petersi also inhabits the State of Mexico but not yet recorded from there. A similar situation occurs for $R$. dulcis, the other species not yet recorded in the State of Mexico, but due to its secretive habits and tiny size, this snake might also likely occur in the State of Mexico.

Mexico City shares 49 of its amphibians and reptiles with Morelos (77.8\%; Table 4). The lower percentage of shared species compared to the State of Mexico is partly due to the fact that Morelos is not within the Basin of Mexico; however, part of it is included in the physiographic province of the Neovolcanic Axis, subprovince of Lagos y Volcanes de Anáhuac. In addition, less temperate forest is present in Morelos, and Morelos is smaller compared to the State of Mexico (Lemos-Espinal and Smith 2020). These characteristics result in fewer species shared with Morelos than with the State of Mexico. Seven of the 14 species that Mexico City does not share with Morelos probably inhabit this latter state, but they have not been recorded yet (Ambystoma velasci, Sceloporus anahuacus, Diadophis punctatus, Geophis bicolor, G. petersi, Thamnophis melanogaster, and T. pulchrilatus) (Lemos-Espinal and Smith 2020).

\section{Acknowledgements}

We thank Jesús Sigala for very helpful comments that greatly improved the manuscript. Support for this study was provided by Dirección General de Asuntos del Personal Académico, Programa de Apoyo a Proyectos de Investigación e Innovación Tecnológica (DGAPA-PAPIIT) through the Project IN215418. We are grateful to A. Núñez Merchand from the National Commission for the Understanding and Use of Biodiversity (CONABIO) for kindly creating and providing the municipality, topographic, physiographic, climate, and vegetation maps used in this publication, and to I. Cruz, also from CONABIO, for providing the satellite images of Mexico City. We are grateful to A. Resetar and J. Mata from the Field Museum of Natural History, Chicago, Illinois; E.M. Braker from the University of Colorado Museum, University of Colorado at Boulder, Colorado; J. McGuire, C. Spencer, and D. Wake from the Museum of Vertebrate Zoology at Berkeley, University of California at Berkeley, California; and D. Dickey and D.A. Kizirian from the American Museum of Natural History, New York. 


\section{References}

AmphibiaWeb (2020) AmphibiaWeb University of California, Berkeley, CA, USA. https:// amphibiaweb.org [Accessed on: 2020-1-10]

Baird SF (1854) Descriptions of new genera and species of North American frogs. Proceedings of the Academy of Natural Sciences of Philadelphia 7: 59-62.

Boulenger GA (1894) Catalogue of the snakes in the British Museum (Natural History). Volume II., Containing the Conclusion of the Colubridae Aglyphae. British Museum of Natural History, London, xi, 382 pp.

Caro-Borrero A, Carmona Jiménez J, Mazari Hiriart M (2016) Evaluation of ecological quality in peri-urban rivers in Mexico City: a proposal for identifying and validating reference sites using benthic macroinvertebrates as indicators. Journal of Limnology 75: 1-16. https:// doi.org/10.4081/jlimnol.2015.1304

CONABIO [Comisión Nacional para el Conocimiento y Uso de la Biodiversidad] (1997) "Modelo Digital del Terreno". Escala 1:250 000. Mexico.

Contreras V, Martínez-Meyer E, Valiente E, Zambrano L (2009) Recent decline and potential distribution in the last remnant area of the microendemic Mexican axolotl (Ambystoma mexicanum). Biological Conservation 142: 2881-2885. https://doi.org/10.1016/j.biocon.2009.07.008

Cope ED (1885) Twelfth contribution to the herpetology of tropical America. Proceedings of the American Philosophical Society 22: 167-194.

Dixon JR (1957) Geographic variation and distribution of the genus Tomodactylus in Mexico. Texas Journal of Science 9: 379-409.

Downs FL (1967) Intrageneric relations among colubrid snakes of the genus Geophis Wagler. Miscellaneous Publications Museum of Zoology, University of Michigan 131: 1-193.

Dugès AAD (1888) Erpetología del Valle de Mexico. La Naturaleza. Serie 2. México 1: 97-146. Frost DR (2020) Amphibian Species of the World: an Online Reference. Version 6.1 (10 January 2020). American Museum of Natural History, New York. https://doi.org/10.5531/ db.vz.0001

Gadow H (1908) Through Southern Mexico: Being an Account of the Travels of a Naturalist. Witherby \& Co., London, 527 pp.

García E, Comisión Nacional para el Conocimiento y Uso de la Biodiversidad (CONABIO) (1998). Climas (Clasificación de Köppen, modificado por García). Escala 1:1 000 000. Mexico.

García-Vázquez UO, Méndez de la Cruz F (2016) Reptiles. In: La Biodiversidad de la Ciudad de México, Vol. 2. CONABIO/SEDEMA, México, 390-397.

García-Vázquez UO, Trujano-Ortega M, Casas-Andreu G (2016) Anfibios. In: La Biodiversidad de la Ciudad de México, Vol. 2. CONABIO/SEDEMA, México, 383-389.

Gobierno del Distrito Federal (2005) Acuerdo por el que se aprueba el programa de manejo del Área Natural Protegida con carácter de Zona de Conservación Ecológica "Sierra de Santa Catarina”. Gaceta Oficial del Distrito Federal 98. http://paot.org.mx/centro/programas/ manejo/santacatarina.pdf

Griffiths RA, Bride IG, Meléndez A, Álvarez-Romero JG, Arana F, Arroyo IA, Benítez H, Buley K, Bustamante E, Chaparro D, Chávez JM, Contreras AV, Díaz M, Gual F, Ibáñez 
R, Leyaz A, Marín AI, Martínez S, McKay J, Millán E, Mistry E, Molina A, Morales O, Mosig P, Núñez J, Olivera C, Ortiz Y, Pérez-Gil R, Ramos P, Reséndiz J, Reyes O, Rivas M, Romero AP, Rosas I, Sandoval, Sarina N, Servín E, Sherezada E, Solzoor A, Steck A, Stephan-Otto E, Valiente E, Vanegas C, Wilkinson R (2004) The conservation of the axolotl (Ambystoma mexicanum) in Xochimilco, Mexico City: a species/habitat action plan. Produced by the Darwin Initiative International Seminar-Workshop held at UAMXCIBAC, Dec. 6-9, Mexico City. Durrell Institute of Conservation and Ecology (DICE), University of Kent, Canterbury.

Günther ACLG (1868) Sixth account of new species of snakes in the collection of the British Museum. Annals and Magazine of Natural History (Series 4) 1: 413-429. https://doi. org/10.1080/00222936808695725

Heider K, López JMR, Scheffran J (2018) The potential of volunteered geographic information to investigate peri-urbanization in the conservation zone of Mexico City. Environmental Monitoring and Assessment 190: 219. https://doi.org/10.1007/s10661-018-6597-3

Hernández-Flores M de la L, Otazo-Sánchez EM, Galeana-Pizaña M, Roldán-Cruz EI, RazoZárate R, González-Ramírez CA, Galindo-Castillo E, Grodillo-Martínez AI (2017) Urban driving forces and megacity expansion threats. Study case in the Mexico City periphery. Habitat International 64: 109-122. https://doi.org/10.1016/j.habitatint.2017.04.004

Herrera AL (1890) Notas acerca de los vertebrados del Valle de México. La Naturaleza (2a Ser.) 1: 299-342.

Imaz M (1989) Historia natural del Valle de México. Revista Ciencias 15: 15-21.

INEGI (2016) Conjunto de Datos Vectoriales de Uso de Suelo y Vegetación. Escala 1:250 000. Serie VI (Capa Unión), escala: 1:250 000. Edición: 1. Instituto Nacional de Estadística y Geografía, Aguascalientes, México.

INEGI (2017) Anuario estadístico y geográfico de la Ciudad de México 2017. Instituto Nacional de Estadística y Geografía, México.

INEGI (2018) 'Áreas Geoestadísticas Estatales', escala: 1:250000. edición: 1. Instituto Nacional de Estadística y Geografía, Aguascalientes, México.

IUCN (2019) IUCN Red List of Threatened Species, Version 2019.2. https://www.iucnredlist. org [Accessed on: 2019-11-19]

Johnson JD, Mata-Silva V, Wilson LD (2015) A conservation reassessment of the Central American herpetofauna based on the EVS measure. Amphibian \& Reptile Conservation 9: 1-94.

Kennicott R (1860) Descriptions of new species of North American serpents in the museum of the Smithsonian Institution, Washington. Proceedings of the Academy of Natural Science of Philadelphia 12: 328-338. https://doi.org/10.5735/086.047.0401

Lara-Góngora G (1983) Two new species of the lizard genus Sceloporus (Reptilia, Sauria, Iguanidae) from the Ajusco and Ocuilan Sierras, Mexico. Bulletin of the Maryland Herpetological Society 19: 1-14.

Lemos-Espinal JA, Smith GR (in press) A conservation checklist of the amphibians and reptiles of the State of Mexico, Mexico with comparisons with adjoining states. ZooKeys.

Lemos-Espinal JA, Smith GR (2020) A conservation checklist of the herpetofauna of Morelos, with comparisons with adjoining states. ZooKeys 941: 121-144. https//doi.org/10.3897/ zookeys.941.52011 
Méndez de la Cruz FR, Camarillo-Rangel JL, Villagrán-Santa Cruz M, Aguilar-Cortéz R (1992) Observaciones sobre el estatus de los anfibios y reptiles de la Sierra de Guadalupe (Distrito Federal - Estado de México). Anales del Instituto de Biología, Universidad Nacional Autónoma de México, Serie Zoológica 63: 246-256.

Méndez de la Cruz FR, Díaz de la Vega Pérez AH, Jiménez-Arcos VH (2009) Herpetofauna. In: Lot A, Cano-Santana Z (Eds) Biodiversidad del Pedregal de San Ángel. UNAM, Reserva Ecológica del Pedregal de San Ángel y Coordinación de la Investigación Científica, D.F. México, 243-260.

Méndez de la Cruz FR, Zúñiga-Vega JJ, Díaz de la Vega Pérez AH, Lara-Reséndiz RA, Martínez-Méndez N (2007) Anfibios y reptiles. In: Lot A (Ed.) Guía ilustrada de la Cantera Oriente. Caracterización ambiental e inventario biológico. Reserva Ecológica del Pedregal de San Ángel. Coordinación de la Investigación Científica, UNAM., D.F. México, 203-219.

Mendoza-Hernández AA, García-Vázquez UO, Nieto-Montes de Oca A (2008) Sceloporus sugillatus. Herpetological Review 39: 483-484.

Raxworthy CJ, Ananjeva N, Orlov NC (2012) Complete species inventories. In: McDiarmid RW, Foster MS, Guyer C, Gibbons JW, Chernoff N (Eds) Reptile Biodiversity: Standard Methods for Inventory and Monitoring. University of California Press, Berkeley, 209-215.

Recuero E, Cruzado-Cortés J, Parra-Olea G, Zamudio KR (2010) Urban aquatic habitats and conservation of highly endangered species: the case of Ambystoma mexicanum (Caudata, Ambystomatidae). Annales Zoologici Fennici 47: 223-238. https://doi. org/10.5735/086.047.0401

Reygadas-Prado DD (2016) Delimitación del área de estudio y regionalización. La Biodiversidad de la Ciudad de México, Vol. 1. CONABIO/SEDEMA, México, 30-35.

Rodríguez López JM, Heider K, Scheffran J (2017) Frontiers of urbanization: identifying and explaining urbanization hot spots in the south of Mexico City using human and remote sensing. Applied Geography 79: 1-10. https://doi.org/10.1016/j.apgeog.2016.12.001

Santibáńez-Andrade G, Castillo-Argüero S, Vega-Peña EV, Lindig-Cisneros R, Zavala-Hurtado JA (2015) Structural equation modeling as a tool to develop conservation strategies using environmental indicators: the case of the forests of the Magdalena river basin in Mexico City. Ecological Indicators 54: 124-136. https://doi.org/10.1016/j.ecolind.2015.02.022

SEMARNAT (2016) Informe de la situación del medio ambiente en México 2015. Compendio de estadísticas ambientales, indicadores clave, de desempeño ambiental y de crecimiento verde. Secretaría de Medio Ambiente y Recursos Naturales, México. https://apps1. semarnat.gob.mx:8443/dgeia/informe15/tema/pdf/Informe15_completo.pdf

SEMARNAT (2019) Modificación al anexo normativo III, lista de especies en riesgo de la Norma Oficial Mexicana NOM-059-SEMARNAT-2010. Protección ambiental-Especies nativas de México de flora y fauna silvestres-Categorías de riesgo y especificaciones para su inclusión, exclusión o cambio-Lista de especies en riesgo, publicada el 30 de diciembre del 2010 (14 noviembre 2019). Secretaría de Medio Ambiente y Recursos Naturales, México. https://www.dof.gob.mx/nota_detalle.php?codigo=5578808\&fecha=14/11/2019

Smith HM (1943) Summary of the collections of snakes and crocodilians made in Mexico under the Walter Rathbone Bacon Traveling Scholarship. Proceedings of the United States National Museum 93 (3169): 393-504. 
Smith HM, Taylor EH (1950) Type localities of Mexican reptiles and amphibians. University of Kansas Science Bulletin 33: 313-380.

Shaw G, Nodder FP (1798) The Naturalist's Miscellany; or Coloured Figures of Natural Objects Drawn and Described Immediately from Nature. Volume 9. Nodder and Company, London, 287 pp.

Uetz P, Hošek J (2019) The Reptile Database. http://www.reptile-database.org [Accessed on: 2019-12-17]

Wilson LD, Johnson JD, Mata-Silva V (2013a) A conservation reassessment of the amphibians of Mexico based on the EVS measure. Amphibian \& Reptile Conservation 7: 97-127.

Wilson LD, Mata-Silva V, Johnson JD (2013b) A conservation reassessment of the reptiles of Mexico based on the EVS measure. Amphibian \& Reptile Conservation 7: 1-47.

Zambrano González L, Reynoso VH, Herrera G (2003) Abundancia y estructura poblacional del axolotl (Ambystoma mexicanum) en los sistemas dulceacuícolas de Xochimilco y Chalco. Universidad Nacional Autónoma de México. Instituto de Biología. Informe final SNIBCONABIO proyecto No. AS004. México, D.F.

Zweifel RG (1959) Additions to the herpetofauna of Nayarit, Mexico. American Museum Novitates 1953: 1-13.

\section{Appendix I}

Museum collections included in the VertNet.org database records of Mexico City amphibians and reptiles that house specimens of the first record of a species in Mexico City.

AMNH Collection of Herpetology, Herpetology Department, American Museum of Natural History

BMNH Zoological Collection, Natural History Museum (London)

CNAR Colección Nacional de Anfibios y Reptiles, Instituto de Biología, Universidad Nacional Autónoma de México

ENCB Escuela Nacional de Ciencias Biológicas, Instituto Politécnico Nacional

FMNH Division of Amphibians and Reptiles, Field Museum of Natural History

MCZ Collection of Herpetology, Museum of Comparative Zoology, Harvard University Cambridge

MVZ Museum of Vertebrate Zoology at Berkeley, Herpetological Collection

MZFC Colección Herpetológica, Museo de Zoología Alfonso L. Herrera, Facultad de Ciencias, UNAM

ROM Herpetology Collection, Royal Ontario Museum

UMMZ Collection of Herpetology, Museum of Zoology, University of Michigan Ann Arbor

USNM Collection of Herpetology, Department of Vertebrate Zoology, National Museum of Natural History, Smithsonian Institution 